\title{
Salmonella Enteritidis in chicken carcasses and giblets in Southern Chile
}

\author{
Jorge Ulloa ${ }^{1}$, Mario González ${ }^{1}$, Carlos Hernández ${ }^{1}$, Maria Paz Villanueva ${ }^{2}$, Heriberto \\ Fernández ${ }^{2}$
}

${ }^{1}$ Institute of Animal Pathology, Universidad Austral de Chile, Valdivia, Chile

${ }^{2}$ Institute of Clinical Microbiology, Universidad Austral de Chile, Valdivia, Chile

\begin{abstract}
Background: Gastroenteritis caused by Salmonella spp. is mainly related to the consumption of undercooked chicken meat or raw poultry products. The objective of this study was to assess the occurrence of Salmonella spp. in chicken carcasses and giblets commercialized in Southern Chile (Valdivia city).

Methodology: A total of 560 samples were collected from four supermarkets and one poultry products dealer, during two periods (autumnwinter and spring-summer periods), and analysed for Salmonella using standard bacteriological procedures.

Results: Five out of 280 analyzed carcasses $(1.8 \%)$ and one out of $280(0.4 \%)$ chicken giblets were Salmonella positive. The isolation frequency of Salmonella spp. considering the total samples analyzed was $1.1 \%$. Salmonella Enteritidis was the only serotype isolated. No significant differences $(\mathrm{P}>0.05)$ in the isolation rates between the autumn-winter and spring-summer periods were found.

Conclusion: Salmonella Enteritidis was isolated in low frequency from chicken carcasses and giblets commercialized in Southern Chile (Valdivia city); however, in spite of the low frequency of contaminated samples, this kind of food could be a potential vehicle of Salmonella infection to humans.
\end{abstract}

Key words: Salmonella, giblets, carcasses, chicken

J Infect Dev Ctries 2010; 4(2):107-109.

(Received and Accepted 27 October, 2009)

Copyright (C) 2010 Ulloa et al. This is an open-access article distributed under the Creative Commons Attribution License, which permits unrestricted use, distribution, and reproduction in any medium, provided the original work is properly cited.

\section{Introduction}

Gastroenteritis caused by Salmonella is related to the consumption of raw food, foods that were not cooked thoroughly, or cross-contaminated food. The main foods associated with Salmonellosis are eggs and chicken meat [1-2]. Salmonellosis is highly prevalent in developed and developing countries, and, together with campylobacteriosis, is a widely spread zoonosis that has a significant economic impact at the public health and poultry industry levels [3-4]. Therefore, the poultry industry has focused special attention on implementing control measures to reduce the dissemination of the pathogen in the production processes, from breeding farms to commercialization sites [5].

In Chile, there are periodical reports of food poisoning in which poultry products, among others, have been identified as the infection vehicle. For this reason, it is necessary to evaluate the sanitary quality of this type of product [6]. Alexandre et al. (1999) reported the presence of Salmonella Enteritidis in poultry products for human consumption in Santiago,
Chile, thus demonstrating that there is a potential risk for the population consuming this type of food [7].

The objective of this study was to evaluate the Salmonella contamination of refrigerated chicken meat and giblets available for human consumption in the city of Valdivia, in two periods of the year.

\section{Materials and methods}

Type of samples

The analysed samples were obtained from one distributor and four supermarkets from Valdivia, Chile, and corresponded to two producers who were assigned codes A and B. A total of 560 samples were collected: from producer A, 140 refrigerated carcasses and 140 refrigerated giblets (liver, gizzard and heart), and the same amount and type of samples were collected from producer B. Sampling was conducted in two periods, autumn-winter and springsummer. 
Table 1. Isolation frequency of Salmonella Enteritidis in chicken carcasses and giblets.

\begin{tabular}{|l|l|l|l|}
\hline Sample & Number & Positive & \% \\
\hline Carcasses & 280 & 5 & 1.8 \\
\hline Giblets & 280 & 1 & 0.4 \\
\hline Total & 560 & 6 & 1.1 \\
\hline
\end{tabular}

\section{Isolation method}

The traditional technique recommended by Corlett [8] was used for the bacteriological analysis of the samples (enriched broth, selective media, biochemical tests and serology). In brief, the chicken carcasses and giblets were washed in sterile polyethylene bags, with 300 and $150 \mathrm{ml}$ of $1 \%$ peptone broth, respectively, followed by a shaking period of three minutes. Then $30 \mathrm{ml}$ of the washing broth were collected for each sample and added to 30 $\mathrm{ml}$ of $1 \%$ peptone broth and incubated at $37^{\circ} \mathrm{C}$ for 24 hours. Following incubation, two aliquots were drawn from each container; one milliliter was added to $10 \mathrm{ml}$ of selenite cystein broth (SCB) (Merck) and incubated at $37^{\circ} \mathrm{C}$ for 20 hours, and $0.1 \mathrm{ml}$ was added to $9.9 \mathrm{ml}$ of Rappaport Vassidialis Novobiocin broth (Merck). Both samples were incubated at $42^{\circ} \mathrm{C}$ for 24 hours. After incubation, aliquots of the enrichment broths were seeded on two selective media, XyloseLysine-Desoxycholate Agar (XLD) (Merck) and Rambach Chromogen Agar (Merck), and incubated at $37^{\circ} \mathrm{C}$ for 24 hours. Suspicious colonies were identified by means of biochemical tests to the genus level. The Salmonella strains were serotyped at the Enterobacteria Reference Center of the Institute of Public Health of Chile.

\section{Statistical Analysis}

Descriptive statistics were used to analyze the obtained data. Isolation rates from both periods (fallwinter and spring-summer) were compared by $\chi^{2}$ test, using the Epi Info program, version 6.04.

\section{Results}

Salmonella was isolated from 6 out of 560 samples $(1.1 \%)$ of carcasses and chicken giblets commercialized in Valdivia, Chile, with five isolations coming from carcasses and one from giblets (Table 1). From producer A, five samples positive for Salmonella were obtained (one from giblets and four from carcasses), and from producer B one positive sample was obtained (one from carcass). All six isolates corresponded to Salmonella Enteritidis.
No statistically significant differences in the frequency of Salmonella Enteritidis isolation during autumm-winter and spring-summer periods were observed.

\section{Discussion}

There are a vast number of reports in the literature about the isolation of Salmonella in poultry products. According to Prado et al., Salmonella spp. and Staphylococcus aureus are the main bacterial agents in Chile isolated in outbreaks related to foodtransmitted diseases, with eggs and poultry meat being the transmission vehicle for Salmonella [6]. The percentage of isolation obtained in this study $(1.1 \%)$, is lower than that reported by other researchers with similar samplings. In Zambia, Mudenda et al. analyzed 521 chicken carcasses obtained from a slaughterhouse, reporting an isolation frequency of $20.5 \%$ [9]. In Ethiopia, Molla et al. (2003), analyzed 452 carcasses and 312 samples of chicken parts, obtained from different supermarkets. The isolation frequency was $8.3 \%$ and $31.7 \%$ respectively [1]. In Brazil, Silva et al. analyzed 150 frozen chicken carcasses obtained at different points of sale, reporting a Salmonella isolation frequency of $32.0 \%$ [10]. In the Chilean Metropolitan Area, Alexandre et al. reported an isolation frequency of $8.3 \%$ and $12.9 \%$ in chicken meat and parts, respectively, with the most prevalent serotype being Salmonella Enteritidis [7].

The difference between the results obtained in this study and those reported by previous studies could be a consequence of several factors. Some researchers discussed the detrimental effect of the refrigeration temperatures on the microorganisms, which make their recovery more difficult [11]. Therefore, the results obtained depend on when the sample was collected during the production process since greater isolation frequency was obtained from samples collected at the slaughterhouse, rather than the those collected at a supermarket or other commercial premises where the products are kept suitably cooled [9]. Another factor to consider is the technique employed. The traditional technique (selective enrichment broth, media, biochemical tests 
and serology) has a good sensitivity; nevertheless, simultaneous use of two techniques significantly increases the number of isolates. Reginato et al. compared the traditional technique (used in this study) with the immunomagnetic separation technique to detect Salmonella in poultry-related products and concluded that the sensitivity increases when both techniques are used simultaneously [12].

Although the number of isolations was relatively higher in the second period (spring-summer), the difference with the first period (autumn-winter) was not significant. This could be explained because in both periods the cooling chain had been managed properly. The isolation frequency of Salmonella obtained in poultry products in Valdivia would probably increase if two isolation techniques were used simultaneously in order to increase sensitivity, as reported by Alexander et al. [7].

Although our results indicate a low isolation frequency, Salmonella Enteritidis is a serotype that could be found in chicken carcasses and giblets, which could be a vehicle of Salmonella infection to humans. In order to prevent food poisoning problems caused by Salmonella, it is necessary to reinforce education programs directed to the population related to the correct handling and cooking of these products.

\section{Acknowledgements}

The authors acknowledge the Research and Development Bureau from the University Austral de Chile for financial support for this research through Grant DID-2002-41.

\section{References}

1. Molla B, Alemayehu D, Salah W (2003) Sources and distribution of Salmonella serotypes isolated from food animals, slaughterhouse personnel and retail meat products in Ethiopia: 1997-2002. Ethip J Health Dev 17: 63-70.

2. Goncagul G, Gunaydin E, Caru K (2005) Prevalence of Salmonella Serogroups in Chicken Meat. 2005. Turk J Vet Anim Sci. 29: 103-106.

3. Peplow M, Correa M, Stebbins M, Jones F, Davies P (1999) Sensitivity, Specificity, and Predective Values of Three Salmonella Rapid Detection Kits Using Fresh and Frozen Poultry Environmental Samples versus Those of Standard Plating. Appl Environ Microbiol 65: 1055-1060.

4. Zhao C, Ge B, De Villena J, Sudler R, Yeh E, Zhao S, White D, Wagner D, Meng J (2001) Prevalence of Campylobacter spp., Escherichia coli, and Salmonella Serovars in Retail Chicken, Turkey, Pork, and Beef from the Greater Wasshington, D.C. Area. Appl Environ Microbiol 67: 5431-5436.

5. Fuzihara T, Fernandes S, Franco B (2000) Prevalence and Dissemination of Salmonella Serotypes along the Slaughtering Process in Brazilian Small Poultry Slaughterhouses. J Food Prot 63: 1749-1753.

6. Prado V, Solari V, Alvarez I, Arellano C, Vidal R, Carreño M, Mamani N, Fuentes D, O’Ryan M, Muñoz V (2002)
Situación epidemiológica de las enfermedades transmitidas por alimentos en Santiago de Chile. Período 1999-2000. Rev méd Chile 130: 495-501.

7. Alexandre M, Pozo C, González V, Martínez M, Prat S, Fernández A, Fica A, Fernández J, Heitmann I (2000) Detección de Salmonella enteritidis en muestras de productos avícolas de consumo humano en la Región Metropolitana. Rev méd Chile 128: 1075-1083.

8. Corlett D A (1998) HACCP user's manual. Gaithersburg, Md: Aspen Publishers.

9. Mudenda B, Sharma N, Skjerve E, Musonda L (1999) Isolation of bacteria during processing of chicken carcasses for the market in Lusaka, Zambia. Veterinarski Arhiv 69: 191-197.

10. Silva D, Berchieri A, Aparecida S, Teresinha A, Augusto L (2000) Salmonella em carcaças de frango congeladas. Pesq Vet Bras 20: 39-42.

11. Lake R, Hudson A and Cressey P (2002) Risk Profile: Salmonella (non typhoid) in poultry (whole and pieces). Institute of Environmental Science Research Limited Christchurch Science Centre. Client Report 212: 1-63.

12. Reginato A, Pinheiro do Nascimento V, Oliveira M, Ruschel L, da Silveira Luis (2002) Utilization of immunomagnetic separation for detectión of Salmonella in raw broiler parts. Braz J Microbiol 33: 339-341.

\section{Corresponding author}

Heriberto Fernández

Institute of Clinical Microbiology

Universidad Austral de Chile

PO BOX 567

Valdivia, Chile

Phone: 5663 214377: Fax: 5663293300

Email: hfernand@uach.cl

Conflict of interest: No conflict of interest is declared. 